\title{
Foliar copper uptake by maize plants: effects on growth and yield
}

\author{
Absorção foliar de cobre por plantas de milho: efeitos no crescimento e rendimento
}

\author{
Rogério Hidalgo Barbosa ${ }^{\mathrm{I}}$ Luciane Almeri Tabaldi ${ }^{\mathrm{II}}$ Fábio Rodrigo Miyazaki ${ }^{\mathrm{III}}$ Márcio Pilecco ${ }^{\mathrm{IV}}$ \\ Samir Oliveira Kassab ${ }^{\mathrm{I}}$ Daísa Bigaton ${ }^{\mathrm{I}}$
}

\section{ABSTRACT}

A slight increase in the levels of a certain nutrient can cause a significant increase in crop yield or can cause phytotoxicity symptoms. Thus, the aim of this study was to evaluate the effect of foliar application of copper $(\mathrm{Cu})$ on the growth and yield of $D G$ 501 maize. The experiment was carried out between December 2009 and April 2010 in conventional tillage. When plants were with six to eight leaves, $\mathrm{Cu}(0,100,200,300,400,500$ and $600 \mathrm{~g}$ $\mathrm{ha}^{-1}$ ) was applied to the leaves. Treatments were arranged in randomized complete block with five replications. When $50 \%$ of the plants were in flowering, it was evaluated the plant height, culm diameter, height of the first ear insertion, leaf area, and chlorophyll content. At harvest, it was evaluated diameter and length of the ear, yield and thousand grain weight. There was a linear reduction in the plant height and in the height of the first ear insertion with increasing $\mathrm{Cu}$ doses. On the other hand, chlorophyll content, leaf area, diameter and length of ear, thousand grain weight and yield increased at doses up to $100 \mathrm{~g} \mathrm{ha}^{-1} \mathrm{Cu}$, however, decreased at higher doses. Therefore, foliar Cu application at doses higher than $100 \mathrm{~g}$ ha-1 has toxic effect in maize plants with losses in growth and yield.

Key words: fertilization, micronutrient, toxicity, Zea mays.

\section{RESUMO}

Um leve aumento nos níveis de certos nutrientes pode causar um significante aumento no rendimento das culturas ou causar sintomas de fitotoxicidade. Assim, o objetivo deste trabalho foi avaliar o efeito da fertilização foliar com cobre (Cu) sobre o crescimento e rendimento do milho híbrido triplo DG-501. O experimento foi desenvolvido no período entre dezembro de 2009 e abril de 2010, em sistema de plantio convencional. Quando as plantas encontravam-se com 6-8 folhas totalmente desenvolvidas, o Cu (0; 100; 200; 300; 400; 500 e 600 $\left.\mathrm{g} \mathrm{h}^{-1}\right)$ foi aplicado via foliar. Os tratamentos foram arranjados em delineamento experimental de blocos casualizados, com cinco repetições. Quando 50\% das plantas apresentavam-se no período de florescimento, avaliaramse a altura de plantas, diâmetro de colmo, altura da inserção da primeira espiga, área foliar e teor de clorofila. Na colheita, avaliaram-se o diâmetro e o comprimento da espiga, o rendimento e o peso de mil grãos. Houve redução linear na altura de plantas de milho e na altura de inserção da primeira espiga com o aumento das doses de $\mathrm{Cu}$. Por outro lado, os dados de índice relativo de clorofila, área foliar, diâmetro e comprimento da espiga, peso de mil grãos e rendimento aumentaram quando foram utilizadas doses de Cu de até $100 \mathrm{~g} \mathrm{ha}^{-1}$ e diminuíram nas doses maiores. Portanto, o Cu aplicado via foliar em doses maiores que $100 \mathrm{~g} \mathrm{ha}^{-1}$ exerceu efeito tóxico às plantas de milho, com prejuízos no crescimento e no rendimento.

Palavras-chave: adubação, micronutriente, toxicidade, Zea mays.

\section{INTRODUCTION}

Maize (Zea mays L.) is one of the main products of Brazilian agriculture not only in quantitative parameter but also regarding its strategic significance, since it is the basis for animal feed. Maize crop presents a high yield potential (GONÇALVES et al., 2008). However, deficiencies in soil fertility may be listed as one of the main factors responsible for the inability of maize cultivars to manifest their full potential genetic production (FERREIRA et al., 2001;

'Universidade Federal da Grande Dourados (UFGD), Rodovia Dourados-Itahum, Km 12, Cidade Universitária. CP 533, $79804-970$ Dourados, MS, Brasil. E-mail: hidalgo.rogerio@gmail.com.*Autor para correspondência.

IUniversidade Federal de Santa Maria (UFSM), Santa Maria, RS, Brasil.

IIICasa da Lavoura, Dourados, MS, Brasil.

${ }^{\mathrm{IV}}$ Cooperativa Agrícola Mista Nova Palma, Nova Palma, RS, Brasil 
CARVALHO et al., 2004). It is important that studies show the nutritional real needs of the maize crop for each region as well as its responses to fertilization levels and the way in which nutrients are available in order to obtain an increase in its yield.

Cerrado soils are weathered, highly acidic, and contain small amounts of nutrients essential for the cultivation of plants (VENDRAME et al., 2010). In agreement with previous studies, micronutrient deficiencies in Brazil have been observed more frequently in Cerrado soils (LUCHESE et al., 2004). Accordingly, several studies have been directed to the use of micronutrients as a way of increasing the efficiency of plant production and of improving the economic returns to producers (ALAM \& RAZA, 2001). Although copper (Cu) is required in small quantities by maize plants (LEITE et al., 2003), it is essential to make their life cycle complete. When $\mathrm{Cu}$ is provided in quantities below the requirements, a decrease in the crop yield may occur (LUCHESE et al., 2004). Copper occurs in enzymatic compositions of vital importance in plant metabolism and participates in the photosynthesis, respiration, carbohydrate metabolism, nitrogen reduction and fixation, protein metabolism and cell wall (DEMIREVSKA-KEPOVA et al., 2004; GUO et al., 2010). Copper is also important for the plant resistance to diseases (TOMAZELA et al., 2006). On the other hand, the excess of $\mathrm{Cu}$ is cytotoxic due to its role in the catalysis of reactions which generates reactive oxygen species (ROS) ultimately leading to increased oxidative stress in plants (ANDRE et al., 2010). Free $\mathrm{Cu}$ ions readily oxidize thiol bonds within proteins, causing a disruption of their secondary structure (DUCIC \& POLLE, 2005). Furthermore, excessive quantities of $\mathrm{Cu}$ may lead to leaf chlorosis and growth inhibition (BOUAZIZI et al., 2010).

The providing of $\mathrm{Cu}$ to crops can be made directly into the soil in the form of fertilizer, in the plant via foliar fertilizer or in the seed treatment (LUCHESE et al., 2004). Copper application in maize seeds at doses of 1 to $6 \mathrm{~g} \mathrm{~kg}^{-1}$ of seeds decreased the ability of seed emergency without affecting the dry weight of plants that emerged (LUCHESE et al., 2004). In soil, more than $98 \%$ of the $\mathrm{Cu}$ of the solution is complexed as chelated with organic compounds of low molecular weight (FAQUIN, 1997). Moreover, $\mathrm{Cu}$ greater availability is in the range of $\mathrm{pH} 5.0$ to 6.5 . In view of these factors, soil applications may not be effective under particular conditions of soil and climate, such as high organic matter content or hot and humid summer. In these cases, the foliar instead of soil application of $\mathrm{Cu}$ could avoid these problems.

The toxic effect of root-up taken $\mathrm{Cu}$ on growth and development of plants has been largely studied in several plant species (GUO et al., 2010; CHOUDHARY et al., 2012). On the other hand, little is known about $\mathrm{Cu}$ uptake by plant leaves and its effects on growth and yield of crops. The knowledge of the relationships between foliar uptake of metal cations plays a substantial role for foliar fertilization technologies and also for risk assessment of toxic metal penetration into the food chain from plants exposed to rain and toxic fallout (SOLECKI \& KRUK, 2011) as well as to swine wastes (SEGANFREDO, 1999). Thus, the aim of this study was to evaluate the effect of foliar application of different doses of $\mathrm{Cu}$ on the growth and yield of maize plants.

\section{MATERIAL AND METHODS}

The experiment was carried out at the Farm School of Faculdade Anhanguera de Dourados, in Dourados, MS, Brazil, located at $22^{\circ} 13^{\prime} 15^{\prime \prime S}$ of latitude, $54^{\circ} 48^{\prime} 21^{\prime \prime} \mathrm{W}$ of longitude and $430 \mathrm{~m}$ of altitude, from December 2009 to April 2010. The climate of Dourados according to KÖPPEN (1948) is mesothermal humid, Cwa type, with temperature and annual rainfall averages ranging from $20^{\circ}$ to $24^{\circ} \mathrm{C}$ and $1250-1500 \mathrm{~mm}$, respectively.

The soil from the cultivated area is classified as dystrophic red oxisol of clayey texture, with the following chemical characteristics: $\mathrm{pH}$ $\left(\mathrm{H}_{2} \mathrm{O}\right) 5.0$; organic matter $25.09 \mathrm{~g} \mathrm{dm}^{-3}$; P 36.0mg $\mathrm{dm}^{-3} ; \mathrm{Al}^{+3} 0.05 \mathrm{mmol}_{\mathrm{c}} \mathrm{dm}^{-3} ; \mathrm{K} 24.05 \mathrm{mmol}_{\mathrm{c}} \mathrm{dm}^{-3}$;

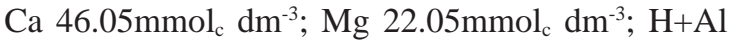
$53.05 \mathrm{mmol}_{\mathrm{c}} \mathrm{dm}^{-3}$; SB $92.15 \mathrm{mmol}_{\mathrm{c}} \mathrm{dm}^{-3}$ and CTC (pH 7.0) 145.2 $\mathrm{mmol}_{\mathrm{c}} \mathrm{dm}^{-3}$; Fe 16.0mg dm ${ }^{-3}$; Cu $2.1 \mathrm{mg} \mathrm{dm}^{-3}$; Zn $13.50 \mathrm{mg} \mathrm{dm}^{-3}$ and $\mathrm{Mn} 22.20 \mathrm{mg}$ $\mathrm{dm}^{-3}$, and $63.46 \%$ of saturation. Accumulation of rainfall during the experiment was $603 \mathrm{~mm}$ and the average temperature was of $25.3^{\circ} \mathrm{C}$ (Max. $31.1^{\circ} \mathrm{C}$ and Min. $18.7^{\circ} \mathrm{C}$ ).

Seeds of triple hybrid maize DG-501 of early maturity with characteristics of grain semi- 
hard, yellow-orange and medium-sized plants were used. Seeds were sown in rows in conventional tillage system after soil preparation. Seeds were treated with the imidacloprid $\left(52.5 \mathrm{~g} \mathrm{ha}^{-1}\right)+$ thiodicarb $\left(157.5 \mathrm{~g} \mathrm{ha}^{-1}\right)$ insecticides and sown at a depth of 5 to $7 \mathrm{~cm}$, spaced $0.90 \mathrm{~m}$ between rows and five plants per linear meter, corresponding to approximately 55,000 plants per hectare. Fertilization was applied at planting with $500 \mathrm{~kg}$ per hectare of N-P-K with the formulation 08-10-10, respectively.

The control of weeds and defoliating caterpillars was carried out 20 days after sowing (DAS) with a backpack pump of 20L, adjusted to 150 $\mathrm{L} \mathrm{ha}^{-1}$, using the tembotrione herbicide (100.8g $\mathrm{ha}^{-1}$ ) and the thiodicarb insecticide (120g ha-1).

Treatments consisted of foliar applications of seven increasing doses of $\mathrm{Cu}(0,100,200,300$, 400, 500 and $600 \mathrm{~g} \mathrm{ha}^{-1}$ ) distributed in a randomized complete block design with five replications of $4 \times 5 m$ each $\left(20 \mathrm{~m}^{2}\right)$. Pentahydrate sulfate copper $\left(\mathrm{CuSO}_{4} \cdot 5 \mathrm{H}_{2} \mathrm{O}\right)(25 \% \mathrm{Cu})$ was used as $\mathrm{Cu}$ source.

The spraying was done when the maize plants were with six to eight leaves fully developed, using backpack sprayer with steady flow equipped with $1 \mathrm{~m}$ bar and with two nozzles spaced at $0.40 \mathrm{~m}$. The spray tip of flat fan TeeJet XR11002 (Dourados/ MS, Brazil) was used to apply 150L ha-1 of spray. The application was made by keeping the tips at $0.30 \mathrm{~m}$ height, approximately, above the top of the plant canopy.

When $50 \%$ of the plants were in the flowering stage, four plants were evaluated per plot. The plant height (using a tape line from the soil until insertion of the last leaf); the stem diameter (measured with a digital caliper at $15 \mathrm{~cm}$ soil); the height of the first ear insertion (using a tape line, measured of the base from the soil to insertion of the first ear); and chlorophyll content (with Falker Clorofilog) were analyzed. After physiological maturity, at the time of harvest, it was evaluated the diameter and length of the ear (with a caliper on four ears per plot), the yield and thousand grain weight (using ears harvested at three meters central to the plot, with the exclusion of the one external row from each side). At harvest, grains had moisture between 13-15\%. Data were subjected to analysis of variance and when significance was found by $\mathrm{F}$ test, data were subjected to regression analysis at 5\% probability.

\section{RESULTS AND DISCUSSION}

With increasing doses of $\mathrm{Cu}$ there was a linear reduction in the height of the maize plants and in the height of the first ear insertion (Figure $1 \mathrm{a}$ and $1 \mathrm{~b}$ ). Genetic studies have shown that these two characteristics have a high correlation between each other (YAN et al., 2010). Plant height is a parameter for assessing crop performance (TITTONELL et al., 2005). Thus, height reduction is a factor that may contribute to the availability of assimilates for grain filling and may, when significant, affect yield. On the other hand, studies have shown that smaller plants do not necessarily affect yield, especially in the absence of water stress (FORTIN \& PIERCE, 1990).

It has been suggested that the primary sites of growth inhibition by excess of $\mathrm{Cu}$ are molecules of chlorophyll of the antenna pigment of photosystem II (LIDON et al., 1993). Even without the significant effect of $\mathrm{Cu}$ on the culm diameter (data not shown), the shortening of internodes in maize plants exposed to Cu may compromise the potential of this extra source of photoassimilates fixed in the culms of the maize plant. These data contradict those reported by LEITE et al. (2003) who found that fertilization with $\mathrm{Cu}$ ranging from 0 to $16 \mathrm{mg} \mathrm{kg}^{-1}$ soil increased significantly the dry weight of shoots of maize plants grown in pots. According to MALAVOLTA (2006), $\mathrm{Cu}$ concentrations in the experimental area were relatively high $\left(2.1 \mathrm{mg} \mathrm{dm}^{-3}\right)$, which may explain the lack of more significant effects of $\mathrm{Cu}$ in maize plants.

On the other hand, both the relative chlorophyll content and leaf area increased at lower doses and decreased at higher doses of $\mathrm{Cu}$ (Figure 1c and 1d). Relative chlorophyll content and leaf area showed maximum points at doses of 257.7 and $112.8 \mathrm{~g} \mathrm{ha}^{-1}$ of $\mathrm{Cu}$, respectively (Figure 1c and $1 \mathrm{~d}$ ). This increase in leaf area and chlorophyll content at lower doses of $\mathrm{Cu}$ can maximize the photosynthetic efficiency of maize plants, which improves the interception of PAR and promotes a more efficient conversion of intercepted radiation into dry matter and photoassimilate partition in the reproductive organs, resulting in higher yield and seed weight. On the other hand, as the leaf is the main source of assimilates to plant maize (MAGALHÃES et al., 1995), the reduction in leaf area and chlorophyll content at higher doses of $\mathrm{Cu}$ may be related 

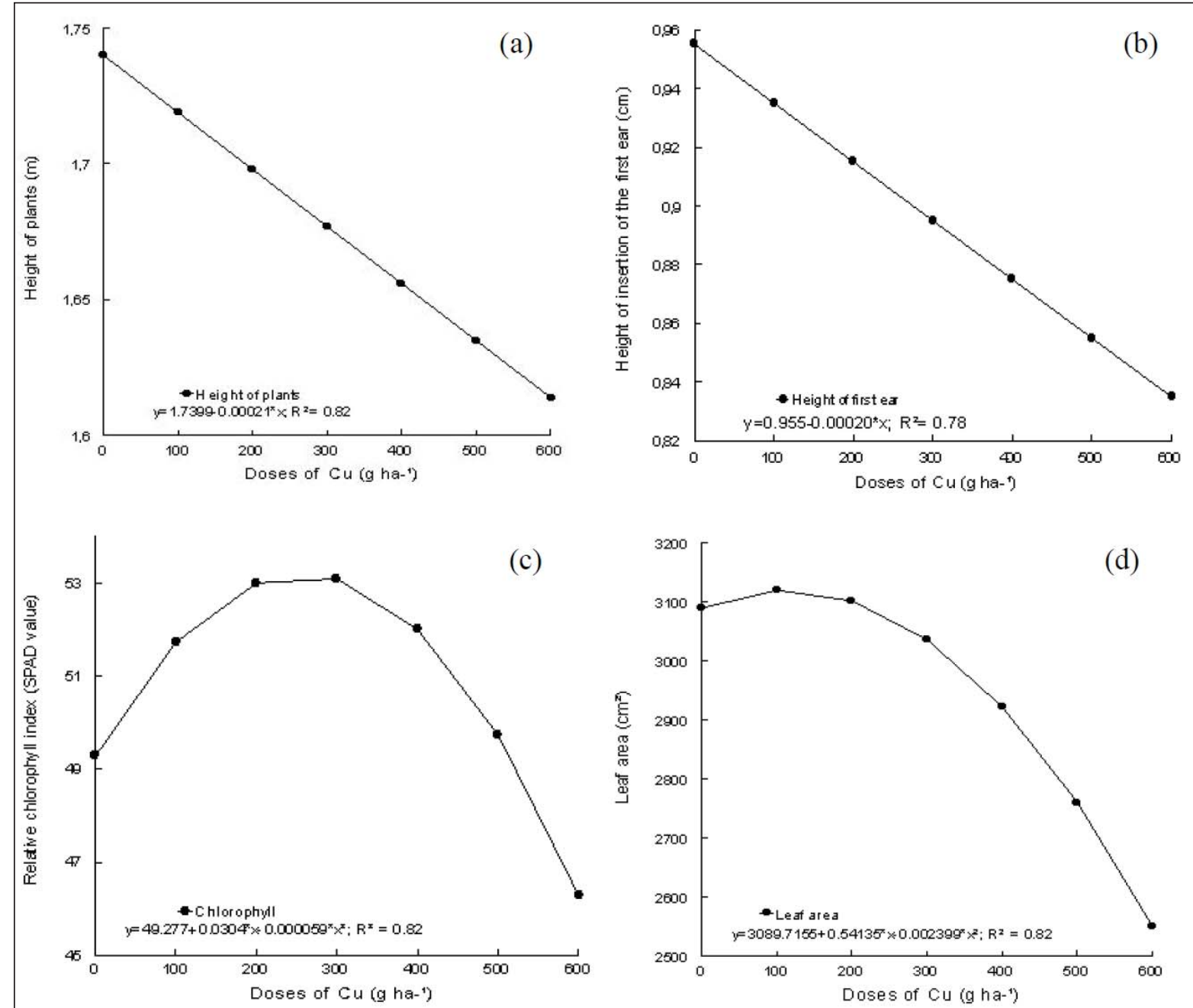

Figure 1 - Plant height (a), height of insertion of the first ear (b), relative content of chlorophyll (c) and leaf area (d) of maize plants submitted to increasing rates of foliar-applied copper. Dourados-MS, 2010. 

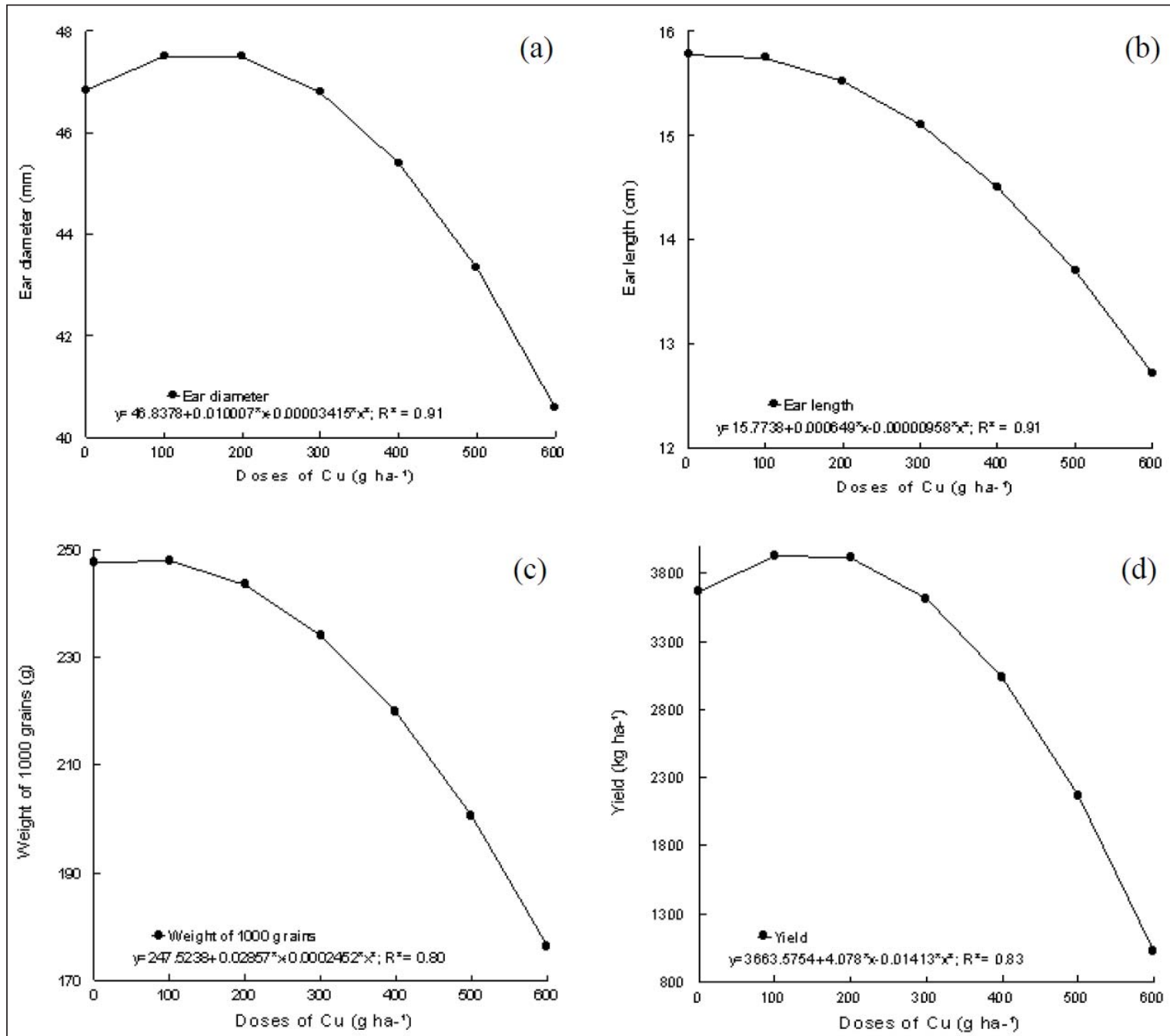

Figure 2 - Ear diameter (a), ear length (b), weight of 1000 grains (c) and yield (d) of maize plants submitted to increasing rates of foliarapplied copper. Dourados-MS, 2010.

Ciência Rural, v.43, n.9, set, 2013. 
to the adverse effects of $\mathrm{Cu}$ on the chlorophyll molecule or interference with enzymes such as ALA deshydratase, an enzyme implicated in the porphyric pathway (SCARPONIL \& PERUCCI, 1984). As a consequence, a reduction in the photosynthetic activity and growth is observed (UPADHYAY \& PANDA, 2009).

As for leaf area and chlorophyll content, data of ear diameter (Figure 2a) and length (Figure $2 \mathrm{~b}$ ), thousand grain weight (Figure 2c), and yield (Figure 2d) showed quadratic response in function of $\mathrm{Cu}$ doses presenting an increase at lower doses and a reduction at higher doses. Ear diameter (Figure 2a) and length (Figure 2b) had maximum points at the doses of 33.87 and $147.44 \mathrm{~g} \mathrm{ha}^{-1} \mathrm{Cu}$, respectively. Moreover, the maximum points for thousand grain weight (Figure 2c) and yield (Figure 2d) were at the doses of 58.26 and $144.29 \mathrm{~g} \mathrm{ha}^{-1} \mathrm{Cu}$, respectively. At the dose of $144.29 \mathrm{~g} \mathrm{ha}^{-1}$, Cu provided an increase of $8 \%$ in maize yield (Figure 2d). These results are related to the data of leaf area and chlorophyll content, indicating that at lower doses Cu promotes an increase in growth and consequently in the yield of maize, whereas at higher doses $\mathrm{Cu}$ becomes toxic to the culture. LUCHESE et al. (2004) observed symptoms of toxicity in treatments with application of $\mathrm{Cu}$ equal or greater than $4 \mathrm{~g} \mathrm{~kg}^{-1}$ seed. These data show that the toxic effects of $\mathrm{Cu}$ at high concentrations affect the growth and grain production.

These data suggest that the reduction in plant height of maize (Figure 1a) at lower doses of Cu did not significantly affect the final yield of these plants. The same did not happen at higher doses of $\mathrm{Cu}$, where a decrease in parameters related to yield was observed. This reduction may be related to the fact that the excess of $\mathrm{Cu}$ inhibits cell elongation, a complex process dependent on cell turgor pressure, synthesis of wall components, and growth regulators (ALAOUI-SOSSÉ et al., 2004). According to LU et al. (2012), yield in maize plants is affected by height reduction since the plant needs to reach a sufficient stature to have adequate photosynthate. Thus, the fine control of cellular concentrations of this metal needs to be strongly adjusted.

\section{CONCLUSION}

Under the conditions that the experiment was carried out, it is concluded that foliar $\mathrm{Cu}$ application at doses higher than $100 \mathrm{~g} \mathrm{ha}^{-1}$ has toxic effect in maize plants with losses in growth and yield.

\section{REFERENCES}

ALAM, S.M.; RAZA, S. Micronutrient fertilizers. Pakistan Journal of Nutrition, v.4, p.1446-1450, 2001. Available from: <http://docsdrive.com/pdfs/ansinet/pjbs/2001/1446-1450.pdf>. Accessed: Sept. 18, 2010.

ALAOUI-SOSSE, B. et al. Effect of copper on growth in cucumber plants (Cucumis sativus) and its relationships with carbohydrate accumulation and changes in ion contents. Plant Science, v.166, p.1213-1218, 2004. Available from: <http://ac.els-cdn.com/ S0168945203005545/1-s2.0-S0168945203005545-main.pdf?_ti

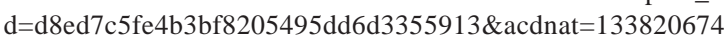
9_8ba77a4ea07175ac9c8cae878fa4a127>. Accessed: Sept. 18, 2010. doi:10.1016/j.plantsci.2003.12.032.

ANDRE, C.M. et al. Dietary antioxidants and oxidative stress from a human and plant perspective: a review. Current Nutrition and Food Science, v.6, p.2-12, 2010. Available from: <http://www.benthamdirect.org/pages/timecorp_viewarticle. php>. Accessed: Nov. 16, 2012.

BOUAZIZI, H. et al. Copper toxicity in expanding leaves of Phaseolus vulgaris L.: antioxidant enzyme response and nutrient element uptake. Ecotoxicology and Environmental Safety, v.73, p.1304-1308, 2010. Available from: <http://ac.els-cdn. com/S0147651310001016/1-s2.0-S0147651310001016-main. pdf?_tid=ff1309e6-3011-11e2-bb2b-00000aab0f27\&acdnat=13 53086642_65ac860c9ea6fdd135ee9326a8196be5>. Accessedn: Nov. 16, 2012.

CARVALHO, M.A.C. et al. Produtividade do milho em sucessão a adubos verdes no sistema de plantio direto e convencional. Pesquisa Agropecuária Brasileira, v.39, p.47-53, 2004. Available from: <http://webnotes.sct.embrapa.br/pdf/pab2004/ janeiro/v39n01a07.pdf>. Accessed: Sept. 10, 2010.

CHOUDHARY, S.P. et al. Interaction of brassinosteroids and polyamines enhances copper stress tolerance in Raphanus sativus. Journal of Experimental Botany, v.63, p.5659-5675, 2012. Available from: <http://jxb.oxfordjournals.org.ez47. periodicos.capes.gov.br/content/63/15/5659.full.pdf+html>. Accessed: Nov. 16, 2012.

DEMIREVSKA-KEPOVA, K. et al. Biochemical changes in barely plants after excessive supply of copper and manganese. Environmental and Experimental Botany, v.52, p.253-266, 2004. Available from: <http://ac.els-cdn.com/ S0098847204000292/1-s2.0-S0098847204000292main.pdf?_tid =52b1310d6d87448b0f0c4188e22e4061\&acdnat=1338213113_ bf12c643047743f8e9f20920f34e58d3>. Accessed: Oct, 10, 2010. doi:10.1016/j.envexpbot.2004.02.004.

DUCIC, T.; POLLE, A. Transport and detoxification of manganese and copper in plants. Brazilian Journal of Plant Physiology, v.17, p.103-112, 2005. Available from: <http://link.periodicos. capes.gov.br.ez47.periodicos.capes.gov.br/sfxlcl41?url_ ver=Z39.88-2004\&url_ctx_fmt=infofi/fmt:kev:mtx:ctx\&ctx_ 
enc $=$ info:ofi/enc:UTF-8\&ctx_ver=Z39.88-2004\&rfr_ id=info:sid/sfxit.com:azlist\&sfx.ignore_date_threshold=1\&rft. object_id=111067612484030\&svc.fulltext=yes $>$. Accessed: Nov. 16, 2012.

FAQUIM, V. Nutrição mineral de plantas. Lavras: UFLA/ FAEPE. 1997. 227p.

FERREIRA, A.C.B. et al. Características agronômicas e nutricionais do milho adubado com nitrogênio, molibdênio e zinco. Scientia Agricola, v.58, p.131-138, 2001. Available from: $<$ http://www.scielo.br/pdf/sa/v58n1/a20v58n1.pdf >. Accessed: Oct. 06, 2010.

FORTIN, M.C.; PIERCE, F.J. Developmental and growth effects of crop residues on corn. Agronomy Journal, v.82, p.710715, 1990. Available from: <http://agris.fao.org/aos/records/ US9050183>. Accessed: Oct. 22, 2010.

GONÇALVES, J.R.A.C. et al. Produtividade e componentes de produção do milho adubado com Cu e NPK em um argissolo. Scientia Agraria, v.9, p.35-40, 2008. Available from: <http:// dialnet.unirioja.es/servlet/fichero_articulo?codigo=2901068 $>$. Accessed: May, 23, 2010.

GUO, X.Y. et al. Toxicity and accumulation of copper and nickel in maize plants cropped on calcareous and acidic field soils. Plant and Soil, v.333, p.365-373, 2010. Available from: $<$ http://link.periodicos.capes.gov.br.ez47.periodicos.capes. gov.br/sfxlcl41?url_ver=Z39.88-2004\&url_ctx_fmt=infofi/ fmt:kev:mtx:ctx\&ctx_enc=info:ofi/enc:UTF-8\&ctx_ver=Z39.882004\&rfr_id=info:sid/sfxit.com:azlist\&sfx.ignore_date_ threshold=1\&rft.object_id=954925434424\&svc.fulltext=yes $>$. Accessed: Nov. 16, 2012.

KÖPPEN, W. Climatologia: con un estudio de los climas de la tierra. México: Fondo de Cultura Econômica, 1948. 479p.

LEITE, U.T. et al. Níveis críticos foliares de boro, cobre, manganês e zinco em milho. Bioscience Journal, v.19, p.115-125, 2003. Available from: <http://www.seer.ufu.br/index.php/biosciencejournal/ article/view/6461/4195>. Accessed: Oct. 03, 2010.

LIDON, F.C. et al. Copper inhibition of rice photosynthesis. Journal of Plant Physiology, v.142, p.12-17, 1993. Available from: <http://dx.doi.org.ez47.periodicos.capes.gov.br/10.1016/ S0176-1617(11)80100-8>. Accessed: Nov. 12, 2010.

LU, Y. et al. Comparative LD mapping using single SNPs and haplotypes identifies QTL for plant height and biomass as secondary traits of drought tolerance in maize. Molecular Breeding, v.30, p.407-418, 2012. Available from: <http://link.periodicos.capes.gov.br.ez47.periodicos. capes.gov.br/sfxlcl41?url_ver=Z39.88-2004\&url_ ctx_fmt $=$ infofi/fmt:kev:mtx:ctx\&ctx_enc=info:ofi/ enc:UTF-8\&ctx_ver=Z39.88-2004\&rfr_id=info:sid/sfxit. com:azlist\&sfx.ignore_date_threshold $=1 \&$ rft.object_ id $=954925620180 \&$ svc.fulltext=yes $>$. Accessed: Nov. 23, 2012.

LUCHESE, A.V. et al. Emergência e absorção de cobre por plantas de milho (Zea mays) em resposta ao tratamento de sementes com cobre. Ciência Rural, v.34, p.1949-1952, 2004.
Available from: <http://www.scielo.br/pdf/cr/v34n6/a44v34n6. pdf $>$. Accessed: Apr. 14, 2010.

MAGALHÃES, P.C. et al. Fisiologia da planta de milho. Sete Lagoas: EMBRAPA-CNPMS, 1995. 27p. Circular Técnica, n.20).

MALAVOLTA, E. Manual de nutrição mineral de plantas. São Paulo: Ceres, 2006. 638p.

SCARPONIL, L.; PERUCCI, P. Effects of some metals and related metal organic compounds on ALA-deshydratase activity of corn. Plant and Soil, v.79, p.69-75, 1984. Available from: $<$ http://link.periodicos.capes.gov.br.ez47.periodicos.capes. gov.br/sfxlcl41?url_ver=Z39.88-2004\&url_ctx_fmt=infofi/ fmt:kev:mtx:ctx\&ctx_enc=info:ofi/enc:UTF-8\&ctx_ver=Z39.882004\&rfr_id=info:sid/sfxit.com:azlist\&sfx.ignore_date threshold=1\&rft.object_id=954925434424\&svc.fulltext=yes $>$. Accessed: Nov. 16, 2012.

SEGANFREDO, M.A. Are swine wastes a fertilizer or a soil pollutant? Cadernos de Ciência \& Tecnologia, v.16, p.129-141, 1999. Available from: <http://seer.sct.embrapa.br/index.php/cct/ article/view/8907/5028>. Accessed: Nov. 16, 2012.

SOLECKI, J.; KRUK, M. Determination of ${ }^{137} \mathrm{Cs},{ }^{90} \mathrm{Sr},{ }^{40} \mathrm{~K}$ radionuclides in food grain and commercial food grain products. Journal of Radioanalytical and Nuclear Chemistry, v.289, p.185-190, 2011. Available from: <http://download.springer. com/static/pdf/170/art\%253A10.1007\%252Fs10967-011-1060-8. pdf?auth66=1353066775_565d496908bc46dc3eb178b156d4c27 8\&ext $=$. pdf $>$. Accessed: Nov. 16, 2012.

TITTONELL, P. et al. Estimating yields of tropical maize genotypes from non-destructive, on-farm plant morphological measurements. Agriculture, Ecosystems \& Environment, v.105, p.213-220, 2005. Available from: <http://ac.els-cdn.com/ S0167880904001483/1-s2.0-S0167880904001483main.pdf?_tid= 4293beac66b2ec1f1972ff02b3b6c453\&acdnat $=1338222423 \_1 e$ f9d711cd0e8a4e7b5a83d1ec3978d1>. Accessed: Oct. 06, 2010. doi:10.1016/j.agee.2004.04.002.

TOMAZELA, A.L. et al. Doses de nitrogênio e fontes de $\mathrm{Cu}$ e Mn suplementar sobre a severidade da ferrugem e atributos morfológicos do milho. Revista Brasileira de Milho e Sorgo, v.5, p.192-201, 2006. Available from: <http://rbms.cnpms. embrapa.br/index.php/ojs/article/view/182/179>. Accessed: Oct. 25, 2010

UPADHYAY, R.K.; PANDA, S.K. Copper-induced growth inhibition, oxidative stress and ultrastructural alterations in freshly grown water lettuce (Pistia stratiotes L). Comptes Rendus Biology, v.332, p.623-632, 2009. Available from: <http://ac.elscdn.com/S1631069109000900/1-s2.0-S1631069109000900main.pdf?_tid=b8344846-3016-11e2-90a4-00000aab0f26\&a cdnat=1353088671_0b68e09330dda7066da76bac2b9e7a89> . Accessed: Nov. 16, 2012.

VENDRAME, P.R.S. et al. Fertility and acidity status of latosoils (oxisols) under pasture in the Brazilian Cerrado. Anais da Academia Brasileira de Ciências, v.82, p.1085-1094, 2010. Available from: <http://www.scielo.br/pdf/aabc/v82n4/26.pdf>. Accessed: Nov. 12, 2010. 
YAN, Z. et al. Stability of QTL across environments and QTL-by-Environment Interactions for Plant and Ear Height in Maize. Agricultural Science in China, v.9, p.14001412, 2010. Available from: <http://ac.els-cdn.com/
S1671292709602315/1-s2.0-S1671292709602315-main. pdf?_tid=2563d6f4bd2d7f041ec0b91c775abe1a\&acdn at $=1338222973$ _a9477deaa2311bbee0f9e608631954ed $>$. Accessed: Oct. 06, 2010. 